\title{
The Attitude of Religious Leaders towards Violence in Nigeria: Case Study of Mosques and Churches
}

\author{
SULAIMAN SHEU ADUA ${ }^{1}$
}

\begin{abstract}
Most of the violence that led to the bloodshed in Nigeria flourished because ofpolitical pungency stage-played through unverified incident wrap-up with faith based encounter. Some of acclaimed religious leader ware turned to political tacticians that focus in helping politician to unleash mayhem in their various community for counter campaign mission which, many of such cases, resulted to carnage that claimed many lives in Nigeria. This manuscript aims to scrutinize the responsibility of a religious leader according to the Scripture (Qur'än and Bible) in quelling any violence cropped-up within their locality or clash between religious sects.To achieve this aims, survey and comparative method used in selecting relevant verses from both Qur'an and Bible to expound the divine responsibility on anyone with religious title. This study finds that, politicians corrupted most of religious leaders in Nigeria to have attached political indulgence to the imperatives of their religion. To the extent that, their major responsibility to submerge the view of their people to harmonize their various community had been exchanged with political assignment that breeds unreceptive violence. Since many of this pastors and Imams were most respected in the society, the paper recommends that, to have peace in Nigeria religious leader should be afraid of Almighty God by not accepting a deal from politicians that can lead to bloodshed and killing of innocent life.
\end{abstract}

Keywords: political propaganda, religion in Nigeria, religious conflict, religious leader, violence

Nigeria, the most populous country in Africa, is bedevilled with various violence that exacerbate by faith-based leader, which consequently caused multiplicity of violence encounter and religion conflict in Nigeria. The country is a multi-ethnic, multicultural, multiregional and multireligious society in which violence features are peculiar to Nigeria, of course managing them has greatly propped up various conflicts, with religious conflict emerging as one of the most devastating of all (Adelani 2011). Religion, as a system of beliefs and practices relating to the sacred, and uniting its adherents in a community, has a powerful hold on people's way of thinking, acting and perception of interests (Kadayıfçı-Orellana 2003).

Violence means that, the state of harmony has been disarray with mayhem, which implies that a normal situation of a place has been disrupted in a dangerous direction and manner that can lead to combative confrontation. According to Akinnaso (2018), violence is the use of intense force, often with the use of some weapons, to coax, threaten, or fatally harm others to get them to surrender their property, themselves, or even their lives. In its milder form, violence may not involve the use of physical weapons but may still inflict harm in some other ways.Due to political indispensable phenomenon, religion has turn to the playing ground of violence and instability in Nigeria.

${ }^{1}$ Sulaiman Sheu Adua, Ph.D., Dept. of Religions, History and Heritage Studies, Kwara State University, MALETE, Nigeria, email: sulaimanadua@yahoo.com. 
Religion is a strong basis for identity, particularly when religious difference coincides with other demarcation lines such as political, ethnic, economic or geographic phenomena. Religious identities are inclusive or exclusive in relation to outsiders. Religion is also social, offering the individual a belonging to an experienced or sensed community of fellow believers (Amina 2009). It is disgusting to note that Nigeria is facing multi-ethnicity and religion violence and is a with three religion viz. Islam, Christian and traditional religion but the focus of this study will be on the two religion with substantial scripture.

Adenugba \& Omolawal (2014), termed religion to be faith in a divinely created order of the world, agreement with which is the means of salvation for a community and thus for everyone who has a role in that community. In this sense, the term applies principally to such systems as Judaism, Christianity, Islam and traditional religion, which involve faith in a creed, obedience to a moral code set down in sacred Scriptures, and participation in common practices(Adenugba \& Omolawal 2014). The three main religions of Nigeria are the Indigenous Religions, Islam andChristianity, with Islam and Christianity having almost equal strength of adherence.While the indigenous religions have generally been, tolerant and accommodating of the two 'guest' religions, contestations and incessant violent clashes havecharacterized the relationship between Muslims and Christians, particularly inNorthern Nigeria, and this has been on the increase in frequency, intensity and sophistication (Adelani 2011).

Although, religious violence in Nigeria has a clear connection with the proliferation of uncompromising Muslim and Christian activism, a relationship that has led to a growing culture of religious violence particularly in northern Nigeria (Afolabi 2016). Religious violence in Nigeria has caused not only physical pain but also psychological, emotional, material, economic and social loss.Discrimination and violence in the name of religion, along with some of the worst injustices in the name of religion has, in fact, been going on throughout the centuries. Religion, in this sense, is a key element underpinning certain conflicts. Although many conflicts and acts of violence were created because of religious differences, religion has also offered unexpected avenues toward peace-making (Amina 2009). Meanwhile, stability is an important condition for the survival of any society in the world. Harmonious co-existence among the inhabitants of any society in the world is likely to bring about peace and stability in such a society.

In this is the age of managerial revolution, leadership in our society exists at the political, societal and managerial levels (Munazza et al. 2014). However, the Islamic leadership in any giving society, is not only concerned with the matters of administration and physical development but it also involves the crucial factor, particularly in the development of the character and the instilling of Islamic values in people to educate them on how to behave and how to work in society (Adnan \& Arifin 2013). In the same vein, the Christian missionary if duly followed the code and conduct of the Holly Bible, will create harmonious atmosphere. Because Jesus modelled himself for as an epitome of messenger ship to his Lord, contrarily, pastors of the $21^{\text {st }}$ century uses the channel of being leader to mislead and exploiting their servant-ship for the sake of self-centeredness.

Furthermore, Nigeria was globally declared as one of the horrible country to subsist in the world because of the widespread of corruption, injustice, violence and lack of security that exposed many innocent lives to end up in the hitch of kidnappers. Not only that, the spate of insecurity and threats to lives and properties in Nigeria has reached alarming proportions despite the increasing visibility of churches and Mosque with their leader. The role of the mosque and the church are important in any given society. Surprisingly, both Christians and Muslims that supposed to control the religious traditions to justify the violence due to their scripture had become sources of inspiration for violent activities. Meanwhile, religious scripture such Quran and Bible is a word of God but should go through human interpretation for proper understanding. The paper will therefore focus on the essence of religious leader and how to spread faith and foster peace building in their various society. 


\section{Impact of Religious Leader in Violence}

Nigeria had been confronted with heinous scenario in ethno religious violence and political crises of monumental proportions due to political henchmen that elusively intercepted religious task with political propaganda, which led to series of violence and religious conflict compounded across the country. The most devastating syndrome in this disorder, is the role of religious leaders that supposed to be peace building agent but turn to monster obtain money or to gain political advantage.

The nature of politic in the olden days is quite different from what we have in this $21^{\text {st }}$ century that every political calamity abounds as a game of violence. Since 1999, it has become impossible for any election to have come-up without blood flown on the street like stream of water. Fact without exaggeration, the number of bloodshed determine the success of political henchmen in current Nigeria. Many of the leaders have tended to plunder, defraud, embezzle, corrupt, and mismanage the process and envy one another with impunity and relish. They have also been possessive, egoistic, selfish, individualistic, callous, greedy and secretive (Olayiwola 2013).

Adenugba\&Omolawal (2014), states that religion permeates the life of every human being as well as every society throughout the world, and every religion has norms, values and acceptable standards contained in its doctrine. By inculcating in adherents these norms and values, religion is expected to promote social control and acceptable standards in the society, thereby reducing vices such as violence and corruption. This paper observed that socio-political, economic developments and religion of a nation are determined by the quality and level of faith of their leaders. The use and abuse of religion to pursue political ends has been common in Nigeria especially in this $21^{\text {st }}$ century. People throughout the region generally see conflict between religious groups as less of a problem than unemployment and kidnapping, crime or political corruption meanwhile, religious violence is the major factor that creates the abovementioned vices.

It is repulsive to note the involvement of so-called religious leader that allow politician to use their place of warship as corner stone of political blue print, which cause a restiveness to the citizen especially those who have nothing to do with politics. In the same vein, many brutal violence that claimed lives and lose of blood occur as implication from the scriptures due to erroneous interpretation of religious leader. Such interpretation was done only to favour their hidden agenda to get money or to promote political party.

Some of the acclaimed religious leader ware turned to an agent helping politician to unleash mayhem in their various community by quoting scriptures wrongly for counter campaign mission which, many of such cases, resulted to carnage that claimed life of dozens of men and women, old and children in Nigeria. There is no gainsaying the fact that ignorance is one of the major reason for the religious violence in Nigeria because people with halfknowledge of the true teaching of the religion are the people involved because they claimed to be defending their religion and can go to any lent without thinking of religious principles.

Many of these religious leaders, which this paper will not mention their names in order not to undermine any religious privacy, have accumulated personal fortunes through crime and violence from political patronage that might cause loss of life but they will twist it as a religious combat to attain divine reward. In an Islamic context, leadership is based on integrity and justice as it is an explicit contract between a leader and his followers that he will try his best to guide them, protect them, and treat them justly. A leader is expected to exercise influence in forming and accomplishing the targeted ethical goals and objectives (Munazza et. al. 2014).

There is no greater need in our twenty-first century world than effective and competent leadership. Our greatest challenge is that of a leadership vacuum. The number one need all over the globe today is not money or new government, it is quality, moral, discipline and principle-cantered leadership. The church as a human institution is not exempted. It has 
faced several inconsistencies in its leadership procedures in contemporary times. This can only be solved by quality leadership with a sense of morality. Leaders of the church need to be principled and disciplined when carrying out their responsibilities (Esther 2013).

However, religion does not only prepare adherents for life everlasting after the existence in the physical world, but also to ensure that adherents live a holy and pure life. Hence adherents are expected to imbibe some values and virtues to promote peace within the society. This implies that religion serves as a means of social control. Unfortunately, religion as practiced by both religious leaders and followers in Nigeria today, has become commercialized to the extent that anything goes. (Adenugba \& Omolawal 2014). In the olden days, the religious leaders are the respected personality because they adhere to the direction of Shari' ah even their cloth may be frumpy, dwelling in antiquated house or eating decrepitude food yet they lived as a sentinel to checkmate politician and direct them to discharge epitome leadership for the people.

Today Nigerian democracy is being characterized by insecurity such as ethnic conflicts, political violence, religious crises, as well as widespread poverty which retard any meaningful development in the country (Ibrahim 2014).Tens of thousands of people have perished in Nigeria over the last five years due to violencebetween Christians and Muslims.

\section{Conceptual Framework}

It is evident that most of the violence that led to the bloodshed in Nigeria occurs because of political pungency staged through unverified incident wrap-up with faith based encounter. Many political leaders have used this unique power of religiontolegitimate their policies and for mobilizing people towards theirconstructed ends. Although the main reasons and issues of a conflictmay not be of religious character, but in most cases religion plays a significant role attimes of conflict where different religious systems encounter oneanother (Kadayıfçı-Orellana 2003).

There are several causal diagnoses of religious conflicts in Nigeria, but much of the literature in this area pay premium attention to the underlying socio-political, economic and governance factors that precipitate, not only religious, but violent conflicts generally. Several political problems take on religious dimensions; manipulated by politics, poverty, illiteracy and ignorance in Nigeria. Violence based on religious affiliation and religious policies has indeed caused physical and psychological damage to several people, thereby legitimizing religious schism among Nigerians who simply have different religious affiliations (Afolabi 2016). Both Christians and Muslims are actively involved in campaigns of hatred against each other. Muslims believe that Christianity does not recognize Islam as a religion that is entitled to exist and consequently it does not recognize their (Muslims) other rights (Omotosho 2003).

It is significance to note that, Islam does not permit any Muslim to live without having a leader in any situation even if they are on a trip or in a desert. Though, the primary duties of a leader are to lead the people in offering prayers, to look after their interest with justice and run their activities in a disciplined and systematic way (Ahmad 2006). Leadership can be defined as a dynamic relationship based on mutual influence and common purpose between leaders and collaborators in which both are moved to higher levels of motivation and moral development as they affect real, intended change.

Islam is a religion that puts emphasis on the overall human life. It covers all aspects of the physical body, the soul or the spirit, the emotion and the intellect with the sole purpose of producing individuals who are able wholeheartedly enslave themselves to the Allah almighty in all sectors of their lives (Adnan \& Arifin 2013).

However, this paper discovered that, one of the reasons why the blood continues to flow in the street in Nigeria, is that, government underrate the impact of religious leader towards initiation of violence from within their various place of worship. There is concern about Muslim extremism and unreliable Imam but the level at which Christian missionary advocate their faith 
to support political agenda is alarming and need to be checked. Since religious leader (Imam and Pastors) were legitimate with religious mandate to institutionalize the interpretation of the religious text their role in the society can never be over emphasized.

Preliminary research has shown that there are different perceptions of leadership in the Christian church today. Among other things, some perceive leadership as a position of power, authority and autocracy. Christian leadership should not be placed on a platform of rivalry where one wishes to be greater than the other, since this practice is worldly. Jesus corrected his disciples when he heard them arguing about who should be first among them (Esther 2013).

Some time, politicians use religious extremism from both sides to cause violence in the society. This paper intends to illuminate the fact that, religion can bring social, moral, and spiritual resources to the peace-building processes and nonviolent environment. The focus of this paper is to emphasize on the fact that, religious leaders must have potential skill to influence policy and law making as well as the people in the wider context. They also function as mediators for conflict resolution. They were involved as representative in dialogue at the beginning of interfaith conflict or interfaith dialogue programmes, during the time of the conflict, at the post-conflict period, as well as the dialogue that are moving toward reconciliation (Khairulnizamet et. al. 2014).

\section{An Overview of the Mosque and the Church}

Throughout history, Muslim communities have always been attached, in one form or another, to the mosque which was not only restricted to being a place of worship, but also perceived as a location for performing rituals, or a social and political dimension of the Muslim community. Instead, it has served as a symbol of belonging and identity (Zakaryya 2010).

Furthermore, the word masjid in terms of etymology is rooted to be "any place in which one can perform the acts of sujud (prostration), or acts of worship or devotion; a house of prayer. The Masjid is not only the place of special buildings for Muslims to commit acts of worship but also the main medium for the propagation of the message of Islam. It became a major centre and foundation of the local community in spreading Islam (Nangkula 2016).

On the other hand, church according to biblical understanding is a place where a body of believers gathered with a specific nature and purpose specially to preach word of God. Jesus understood very well that the church and the world will always be linked as the church comes from the world, and they influence each other continually. Which means, a church is a community of people tied by common life principles that make them different from the rest of society though taken from the larger community (Pablo-George 2010).

There is consenting opinion on the literary meaning of church within the Christian missionary. Some believe it as place of worship while some take it as an assembly of God. congregation or meeting place. Nevertheless, Church is a place where God's words are preaching to the member except if the pastor missionary platform to acquire personal gain. Some churches have acknowledgeable that biblical reflection and preaching plays a central role in quelling conflict. The pragmatic efforts of ancient churches give an idea about the crucial role of leadership in combating the incessant bloodshed but this $21^{\text {st }}$ century witness a lot of missionary anarchism that allow politician to infiltrate their faith.

Many churches and their leaders have neglected and abandoned this role and only concentrate on people in the church to the neglect of the rest who are outside and are poor in spirit. Many are also under the captivity of diverse affliction without getting people to preach the good news to them (Esther 2013). 


\section{Leadership in Islamic Perspective}

The Quran is a continuing source of guidance, and the guidance it offers is in the context that covers all the previous sacred books because there is no sacred scripture that speaks about nature and earth as much as the Quran. It contains numerous guidelines about our treatment of the earth and the rest of God's creation so much so that the Quranic revelation intimately connects itself with the notion of sacredness of nature. Muslims base their behaviour as leader and or as follower upon the Word of God as revealed in the glorious Quran.They believe that the Prophet of Islam, Muhammad, has modelled the way for Muslim leaders and followers for all times. To this end, Quran says:

To thee We sent the Scripture in truth, confirming the scripture that came before it, and guarding it in safety: so, judge between them by what Allah hath revealed, and follow not their vain desires, diverging from the Truth that hath come to thee. To each among you have we prescribed a law and an open way. If Allah had so willed, He would have made you a single people, but (His plan is) to test you in what He hath given you: so, strive as in a race in all virtues. The goal of you all is to Allah; it is He that will show you the truth of the matters in which ye dispute (Yusuf Ali: Quran 5:48).

The Quran also explains its worldview by telling the story of the origin of man. It introduces the story of creation through a conversation between God and the angels (2: 30-39; 15: 28-44; 38: 69-74). One will find similarities between the stories of creation in the Quran and in the Old Testament(Ibrahim 2014). Although one may believe that religious texts, such as the Quran, is the direct word of God, it still must go through human interpretation which means the idea of interpreter may influence the understanding of the listeners. The Quran clearly underlines the role of the individual and of the community in establishing a government.

We have sent down to thee the Book in truth, that thou mightiest judge between men, as guided by Allah: so be not (used) as an advocate by those who betray their trust (Yusuf Ali: Quran 4:105)

Islam is a complete way of life which comprehensively covers the totality of human life on earth. These aspects of human life which Islam governs, include the spiritual, political, economic, social, educational, personal, interpersonal, national affairs, judiciary and constitutional aspects. The Quran and Islam can best be compared to nature itself most especially regarding leadership. Therefore, the issue of leadership and good governance can be found within the premise of Islam (Muhammad Sani 2014).

Meanwhile, it is difficult to define religious leader with single content because of its complexity and duty formed ahead to spearhead all their social, economic and political issue. Quran referred to religious leader in many places as Imam, Khalifa, Ulu al-Amr among others. Generally, leadership comes with a purpose or purposes to be fulfilled. In Islamic perception, Leadership centres on trust (amanah) because it represents a psychological contract between leaders and their followers that they will try their best to guide, protect and treat their followers justly. It revolves on doing good deeds for the sake of Allah, the Muslim community and humankind (Mahazan et. al. 2015). al-Quran says

O David! We did indeed make thee a vicegerent on earth: so, judge thou between men in truth (and justice): Nor follow thou the lusts (of thy heart), for they will mislead thee from the Path of Allah: for those who wander astray from the Path 
of Allah, is a Penalty Grievous, for that they forget the Day of Account (Yusuf Ali: Quran 38:26).

A leadership without any single purpose is never a leadership. In Islamic leadership, regardless of its any level and areas covered, purports towards the fulfilment of the rights of God (Mahazan et. al.2015). Therefore, leadership is an essence, which through this essence series of intellectual and humanistic abilities and capabilities could be mixed and by managing and controlling this essence organization goals could be achieved in a better and effective way.

Islam prescribes very high qualification for a divine leader. A religious leader should be the most knowledgeable, the wisest, and the most gallant of all. He should also be immune from every kind of sin, mistake and error. Leadership is the process of influencing people and making them do certain things. It is both an art and a science. It has rational, emotional, intuitive and instinctive dimensions. A few leadership skills are innate but most are acquired by experience and education.

In Islam, all activities are based on three basic principles, namely all wealth and resources belong to God, human beings manage God's wealth and resources as trustees, and the most loved by God are those who are most pious, helpful and useful to other creations, including humans, animals and the environment. Islamic management was derived because of these socio-economic and theological principles. The leader is obliged to exemplify openness, a willingness to listen and compassion in dealing with subordinates or followers (Munazza et.al.2014).Leadership involves moving followers in a certain direction mostly by non-coercive methods. Successful leaders get voluntary co-operation from followers. Good leaders persuade and do not command; they pull and do not push. Leaders who depend only on authority and coercion do not go very far because poor leaders use contrast manipulate over their followers and Manipulation is getting a person to do what they are not aware of or do not want to do.

It is part of the Mercy of Allah that thou dost deal gently with them Wert thou severe or harsh-hearted, they would have broken away from about thee: so pass over (Their faults), and ask for (Allah's) forgiveness for them; and consult them in affairs (of moment). Then, when thou hast Taken a decision put thy trust in Allah. For Allah loves those who put their trust (in Him) (Yusuf Ali: Quran 3:159).

If practiced, the principles of Islamic Leadership practiced by Prophet Muhammad and subsequently by his Caliphs and pious followers will lead to success for both Muslims as well as non-Muslims (Munazza et. al. 2014). The basis of leadership should be fundamentally based on wisdom and spirited debate, otherwise followers become resentful and dissatisfied. The role of a receptive leader is captured in the Quranic instructions in chapter 16:125 stated which means

Invite (all) to the Way of thy Lord with wisdom and beautiful preaching; and argue with them in ways that are best and most gracious: for thy Lord knoweth best, who have strayed from His Path, and who receive guidance (Yusuf Ali: alQuran 16:125).

The principles of Islamic leadership compiled by Muslim authors are endless. The Prophet of Islam (PBUH) was a positive thinker and his activities were always result oriented through all such of principles and among these principles practiced by Prophet Muhammad are begin from the possible, see advantage in disadvantage, change the place of action, make a friend out of an enemy, turn minus into plus, the power of peace is stronger than the power of violence, not to be a dichotomous thinker, to bring the battle in one's own favourable field, 
gradualism instead of radicalism, and to be pragmatic in controversial matters (Khairulnizam \& Suzy2014).

\section{Leadership in Christian Perspective}

Nigerians relate with supernatural realities through prayers, supplications, fasting and offering of sacrifices. Ever since the spread of the gospel to the country, Nigerians have embraced and adopted and practiced it with favour and passion. In the recent past, the spirit of 'born againism' has taken over. Churches are found in all nooks and crannies of the streets. There are churches in the forests, riversides, on hilltops and mountains. Crusades are organized daily;worship sessions and vigils take place every minute of every day of the week. Meanwhile, some of these churches have even become venues for corrupt politicians (who come with all the paraphernalia of office) to campaign and to give thanks to God after 'winning' elections which were believed to have been rigged. They are at times, given the microphone to address the congregation and give account of their stewardship (Adenugba \& Omolawal2014).

Esther (2013) asserts that, Jesus Christ left a pattern of leadership for the disciples to follow. A pattern in this sense could be taken as an original form used in reproducing another of its kind. Jesus Christ expects leaders of his church to reproduce a kind or the type of leadership he taught the first leaders. The church of yesterday was based on truth, purity and holiness; this is now hard to find in today's church. Over here in Nigeria, there are far more people behind the pulpit that have no right to be there than there are those who have truly been called by God and do have the right to be there. On one hand the church in all ages has been an arena where countless persons have been saved and transformed, where dedicated men and women have devoted their lives to unselfish service to God and humanity, and where the highest ideals of human history have been enshrined and cherished. On the other hand, the church in every age has been the scene of obscene cruelty and viciousness, of self-serving power struggles and corruption, of hypocrisy and sanctimoniousness. Contrarily, the pulpits of Nigeria are filled with men and women who are involved in all manner of immorality because of bad leadership in the church.

It is interesting to note that most foundational religious texts contain teachings on good governance. The Bible, for example, strictly requires its followers to fulfil promises and contracts and to ensure accuracy in weights and measures. It not only strongly endorses truthfulness, sincerity and honesty and condemns lying and cheating, but it also highlights the responsibility of the strong and powerful in society to protect and respect the weak, powerless and poor. In this regard, Mathew 23:1-8 is one of the biblical verses which set out to set out principle of a good leadership because Jesus Criticizes the Religious Leaders, thus;

1Then Jesus said to the crowds and to his disciples, 2 "The teachers of religious law and the Pharisees are the official interpreters of the law of Moses. ${ }^{3}$ So practice and obey whatever they tell you, but don't follow their example. For they don't practice what they teach. ${ }^{4}$ They crush people with unbearable religious demands and never lift a finger to ease the burden. 5 "Everything they do is for show. On their arms, they wear extra wide prayer boxes with Scripture verses inside, and they wear robes with extra-long tassels. ${ }^{6}$ And they love to sit at the head table at banquets and in the seats of honour in the synagogues. ${ }^{7}$ They love to receive respectful greetings as they walk in the marketplaces, and to be called 'Rabbi.'" "Don't let anyone call you 'Rabbi,' for you have only one teacher, and all of you are equal as brothers and sisters. ${ }^{9}$ And don't address anyone here on earth as 'Father,' for only God in heaven is your Father. ${ }^{10}$ And don't let anyone call you 'Teacher,' for you have only one teacher, the Messiah. ${ }^{11}$ The greatest among you must be a servant. ${ }^{12}$ But those who exalt themselves will be 
humbled, and those who humble themselves will be exalted.13 "What sorrow awaits you teachers of religious law and you Pharisees. Hypocrites! For you shut the door of the Kingdom of Heaven in people's faces. You won't go in yourselves, and you don't let others enter either (Matthew 23:1-8).

Despite all the warning against worldly form of leadership by Jesus, it appears some pastors are too worldly. They are interested in material things such as the creation of wealth, purchasing of expensive cars, adorning themselves with gorgeous attires and constructing magnificent buildings. This is believed to be their main concern at the expense of the spiritual development of their members (Esther 2013). Christian leadership is not rooted in worldly notions of success, such as the love of money or power. Jesus Himself spoke against this when expressing the importance of serving others.

Jesus called them to Himself and said: "You know that the rulers of the Gentiles lord it over them, and those who are great exercise authority over them. Yet it shall not be so among you; but whoever desires to become great among you, let him be your servant. And whoever desires to be first among you, let him be your slave - just as the Son of Man did not come to be served, but to serve, and to give His life a ransom for many" (Matthew 20:25-28).

Leadership is the act of influencing or serving others out of Christ's interests in their lives so they accomplish God's purposes for and through them, that is, Leaders are not to oppress and overpower others with their authority, like the Gentiles practiced. Instead, leaders serve others, which Jesus demonstrated thus, when He:

"made Himself of no reputation, taking the form of a bondservant, and coming in the likeness of men. And being found in appearance as a man, He humbled Himself and became obedient to the point of death, even the death of the cross" (Philippians 2:7-8).

It is glaring to be observe that, the role of religious leader in enfranchising their authority is quite unusual especially in term of conflict resolution and interfaith tranquillity, both Muslims and Christian leaders inclusive. This study finds that, most of religious leaders in Nigeria were corrupted by politicians to have attached political indulgence to the imperatives of their religion. To the extent that, the major responsibility vested on them to submerge the view of their people to harmonize their various community had been exchanged with political assignment that breeds violence and bloodshed.

The study observed that, violent mostly occur because of human actions and negative decision making for personal endeavour. The paper therefore suggests that, the essence of religious leader is to spread faith and foster peace building in their various society in this case, the research will not only help individual to realize the responsibility of religious leader but also warn individual to be aware of misconception about the difference between religious right and political violence that emanate from such leader for the self-centred achievement.

The study also discovered that Nigerian of today beleaguered with religious leaders that altered their celestial faith with political ideologies not only to accumulate huge money but also to have access to political appointment and contracts. This research finds that, violence erupted in Nigeria in the name of religion and misconception of scripture, based on this observation, this article explores the relationship between religion and violence and argues that religion can also be a positive force to establish justice, and peace through nonviolent activism with proper exhibition of the scriptures. The paper also recommends that individual must have to be 
forewarn against political propaganda and to have realistic mind to verify any incidence before reacting to it.

\section{References}

Adelani I. Akanji. 2011. Towards a theology of conflict transformation: a study of religious conflict in contemporary Nigerian society. Ph.D. Thesis. University of Edinburgh.

Adenugba, A. A \& Omolawal, S. A. 2014. Religious values and corruption in Nigeria: adislocated relationship. Journal of Educational and Social Research 4(3): 520-525.

Adnan Abd Rashid \& Arifin Mamat. 2013. Educational view of the Islamic leadership: are the Islamic leaders performing their responsibilities? International Journal of Humanities and Social Science 3(3): 178-179.

Afolabi Oluwaseun Olawale. 2016. Religious violence and national security in Nigeria, 19992011. International Affairs and Global Strategy Journal 42: 23-21.

Akinnaso Niyi. 2018. Causes and consequences of violence in Nigeria. Punch News Paper, $4^{\text {th }}$ September. (online) https://punchng.com/causes-and-consequences-of-violence-innigeria. Retrieved: $2^{\text {nd }}$ October 2019.

Amina Rasul. 2009. The Role of religion in peace making. Conference paper. The CSID 10th Annual Conference, May $5^{\text {th }}$.

Esther Dasaah. 2013. Perception and practice of Christian leadership in the deeper life Bible Church. M.A. Thesis. Kwame Nkrumah University of Science and Technology-Kumasi.

Ibrahim, Muhammad Sani. 2014. Qualitative Islamic education as a panacea for resolving leadership and good governance crises in a democratic society. International Letters of Social and Humanistic Sciences 32: 72-80.

Kadayıfçı-Orellana Ayşe. 2003. Religion, Violence and the Islamic tradition of nonviolence. The Turkish Yearbook: Ankara University Journal of International Relations 34: 26-29.

Khairulnizam M.K., Suzy Aziziyana S. \& Khadijah M. K. 2014. Role of religious leader in interfaith dialogue towards conflict resolution: an Islamic perspective. International Journal of Education and Research 2(6): 77-88.

Mahazan A.M., FazrulAzdi W.R., Aishah H. Siti, Yuseri A., Mohd. Rosmizi A.R., Muhammad Y. K. \& M.G. Rumaizuddin. 2015. Leadership behaviors in Islam: integrating managerial leadership and servant leadership. Middle-East Journal of Scientific Research 23(4): 722728.

Munazza S., LukmanThaib \& Mohd. Zaidi Abd Rahman. 2014. Islamization on modern leadership perspective: a conceptual study. International Journal of Multidisciplinary Approach and Studies 1(3): 20-32.

Nangkula U. \& Intan R. M. 2016. The Role of the Masjid in disaster management: qualitative data specifically by informants based on their Eexperiences. Research Journal of Fisheries and Hydrobiolo 11(3): 158-164.

Olayiwola, A.R.O. 2013. Leadership, corruption and governance in Nigeria. Journal of Education and Leadership Development 5(2): 41-58.

Omotosho, Abdulrafii 0. 2003. Religious violence in Nigeria: the causes and solutions: an Islamic perspective. Swedish Missiological Theme 91(4): 15-31.

Pablo-George I. E. 2010.The Local Church as an Agent of Social Transformation in A Poor Community: A Practical and Methodical Approach. M.A. Dissertation. University of Pretoria, South Africa.

Zakaryya Mohamed Abdel-Hady. 2010.The Masjid, Yesterday and Today. Center for International and Regional Studies. USA: Georgetown University. 